\title{
Transhumanism in India: Past, Present and the Future
}

\author{
Sarah Ahamad ${ }^{1}$, Palak Madan ${ }^{1}$, Avinash Kumar Singh ${ }^{1,2, *}$ \\ ${ }^{1}$ India Future Society, ${ }^{2}$ University of Technology Sydney \\ *avinashsingh@outlook.com
}

Transhumanism is the philosophy or theory that hypothesizes that the human species can evolve beyond its present limited physical and mental capacities, especially with the help of science and technology. The Indian subcontinent has a particularly rich cultural heritage, which has a certain level of natural compatibility with the transhumanist core philosophies. From the pursuit of longevity to the morphological freedom exercised by the avatars of ancient polytheistic Gods and Goddesses, the legacy and heritage of ancient Indian civilizations have much more similitude with the radical concepts of transhumanism of the modern ages. Statistics show a significant possibility for India to emerge as one of the revered players in the field of economy, science, and technology by 2050. Such a promising scenario paves a way for ideas like transhumanism to play an important role in shaping the country's future. In addition, a wider acceptance of transhumanist concepts can be easily achieved in India by connecting the common Indian man to his roots, using layman's words instead of strictly academic terminologies.

\section{Transhumanism in Ancient India}

The term Transhumanism is defined as an international intellectual movement that aims to transform the human condition by developing and making widely available sophisticated technologies to greatly enhance human intellect and physiology [1]. Evidence throughout the history of ancient India points towards the direction that transhumanism is a concept which is just not imported from the west in the recent times. Rather transhumanism has been congruent to ancient Indian philosophy, traditions, and culture, since time immemorial.

The inhabitants of the Indian subcontinent [2] have self-ascribed the name "India" or "Bhärata". The name has its roots in Vedas and Puranas where Bharata is the official Sanskrit name of the country and it designates a land, which is seen in the Sanskrit texts written in those times as Bhärata Ganaräjya. The term Bhärata varșam was used to recognize India and to distinguish this land from other varșas or continents [3] .

Rigveda mentions of a Vedic tribe called the Bhāratas [4], who participated in the Battle of the ten Kings [5]. Emperor Bharata unified the Indian subcontinent under one realm. Bharata descended from the Bhāratas tribe, which was a branch of Kuru Dynasty [6].

$$
\begin{aligned}
& \text { उत्तरं यत्समुद्रस्य हिमाद्रेश्चैव दक्षिणम् । } \\
& \text { वर्षं तद् भारतं नाम भारती यत्र संततिः ।। }
\end{aligned}
$$

"The country (varsam) that lies north of the ocean and south of the snowy mountains is called Bhāratam; there dwell the descendants of Bharata. [7]"

Amongst the oldest civilizations of the world, India comes up as one of the most prominent names [8]. The Indian culture comprises several various regional cultures spanning across the Indian subcontinent [9] which is influenced and shaped by several thousand years old histories [10]. Dharmic religions have heavy influenced India along the sands of time [11]. The Dharmic religions have shaped much of Indian 
philosophy, literature, art, music, and architecture [12]. The history of India comprises of separate distinct ages, firstly the prehistoric settlements and societies in the Indian subcontinent; then the intermixing of Indus Valley Civilization and Indo Aryan Culture into Vedic Civilization, which has taken place gradually [13]; Finally, this led to the synthesis of Hinduism which developed as a result of the blending of various Indian cultures and traditions; followed by the emergence of sixteen oligarchic republics termed as Mahajanapadas. In 6th century BCE, this phase was ensured by the development of Śramana movement [14] and eventually Buddhism. History of India thereafter saw the rise and fall of several powerful dynasties spanning around two millennia throughout different geographic location of the country. This span of two millennia saw the flourishing of the Muslim rulers alongside Hindu dynasties and in due course of time the advent of European traders establishing the British Colonial Rule. This led the people of India to revolt for independence and create the Republic of India after almost 200 years of struggle for freedom from the British rule [15].

\section{Transhumanist connection in ancient Indian civilizations}

\section{Indus Valley Civilization}

Urbanization first started in the Indian subcontinent in the $2500 \mathrm{BC}$ in the Indus plains; however, the ancestry, the developmental stages and the beginning of the urban life are still shrouded in mystery. Indus Valley Civilization [16] began at around 3300 BCE. The civilization used Indus script for communication and until date, the script has remained undecipherable.

Throughout the next 1000-1500 years, Indus Valley Civilization witnessed an excellence in techniques pertaining to handicraft (carnelian products, seal carving) and metallurgy (copper, bronze, lead, and tin). The civilization knew how to use a boat and wheel. They had two-wheeled bullock carts and trade was an important source of income. They gained high feats in developing detailed urban designing and planning, baking clay brick houses, systematic drainage, and efficient water supply systems. Then at around 2600 $\mathrm{BCE}$, the cities of Harappa and Mohenjo-Daro became one of the largest metropolises in the world at that period. They also achieved great feats in the fields of architecture and engineering, irrigation technology, standardization of weights, measurements and metallurgy, bread making and pottery, medical science and mathematics. In terms of religion and philosophy, the people had left behind ample amount of idols and figurines symbolizing female fertility. Such findings denote towards the worship of a deity that is actually a mother goddess and can be compared to present day Goddesses Shakti or Kali. Indus Valley Civilization people engraved animal figures in their seals, as an object of reverence, and worshiped them. In the animal figures, the zoomorphic aspects some later day Hindu gods and goddesses manifest. Seals having engravings of Lord Shiva in the Pashupati avatar (lord of the animals) performing yogic postures have been also unearthed [16]. All of this point towards the transhumanist concept of "morphological freedom" exercised by ancient Gods of Indus Valley Civilization. Their culture has contributed significantly to the development of Hinduism, as we see today.

\section{Vedic period}

The Vedic period starts from 1500 BCE. The term 'Veda' means knowledge. The Vedic period of Indian history is remarkable for the thirst of the people at that age to acquire knowledge. Vedic knowledge comprised mainly of physics, mathematics, astronomy, logic, cognition and other subjects. The earliest science that has come down upon the Indian people passing through the sands of time is the Vedic Science [17]. 
Some of the very important concepts, which are at par with the modern transhumanist philosophies, can be found in the Vedas. There are four main Vedas - Rigveda, Samaveda, Yajurveda, and Atharvaveda [18]. The entire Book 9 of The Rigveda (c. 1700-1100 BCE) is tribute to the immortality-ushering "Soma" plant [19]. (Soma is summoned as "Haoma" in ancient Iranian scriptures of Avesta written during 1200-200 BCE.)

Ayurveda is called as the "science of long life" and in India, the "immortal" Rishis or sages, and the Ciranjivas (the "forever living") are respected even in modern times. Ayurveda has a special area exclusively dedicated to super-longevity. The essence of Ayurveda is embodied in the ancient texts of The Sushruta Samhita (Sushruta's Compilation of Knowledge, c. 800-300 BCE), which says:

\begin{abstract}
"Brahma was the first to inculcate the principles of the holy Ayurveda. Prajapati learned the science from him. The Ashvins learned it from Prajapati and imparted the knowledge to Indra, who has favored me (Dhanvantari, an incarnation of Lord Vishnu, the protector of life and the giver of Ayurveda on earth) with an entire knowledge thereof." This knowledge was in turn "disclosed by the holy Dhanvantari to his disciple Sushruta [20]."
\end{abstract}

According to the Sushruta Samhita, the average human life expectancy can be prolonged upto 100 years, naturally. But the formula for super-longevity has also been discussed in ancient Ayurvedic texts which says life can be extended to 500-800 years with Ayurvedic interventions like using certain Rasayana (chemical) remedies (such as Brahmi Rasayana and Vidanga-Kalpa). In addition, the use of the "Soma plant, the lord of all medicinal herbs" [24 candidate plants are named], guarantees reinvigoration of the user and helps him to "witness ten thousand summers on earth in the full enjoyment of a new (youthful) body."

Philosophical thoughts on "Amrit" - अमृत - or the "nectar of immortality" - "a revered and desired substaThose who could grasp the full knowledge of Ayurveda had a chance to live a happy, prosperous and almost immortal life. They "attained the highest well-being and non-perishable life-span [21]." In the Sushruta Samhita, athe ctual surgical methodology of skin graft transplantation to attach severed earlobes and perform rhinoplasty to reconstruct disfigurement of nthe ose, are explained scientifically and vividly[20]. nce" has also been mentioned in these texts.

One of the many foundational texts of Ayurveda, The Charaka Samhita (Charaka's Compilation of Knowledge, c. 300-100 BCE), holds a high value. According to it's scriptures, 100 years is the average human life-span. However, upon following the protocols and using the system of "Amalaka Rasayana", a human being gains the longevity of a century. And that of the use of "Amalakayasa Brahma Rasayana", a person may live up to a millennia [22].

In Mahabharata (written by Vyasa, 400-500 BCE), the severed body of king Jarasandha, could be reanimated completely again by fusing from two halves [23]. Reading such ancient scriptures helps one to understand how medical science has evolved down the ages and clearly aligned with the transhumanist core philosophies.

The monkey king Hanuman in the ancient Indian epic of the Ramayana (.400 BCE), used the Sanjeevani plant (translated as "One that infuses life" and generally referred to the lycophyte Selaginella bryopteris, which is native to the Dunagiri mountain in the Himalayan Mountain Range) to resuscitate Lakshman, Rama's younger brother, who was fatally injured by the demon king Ravana [24]. The accounts of the regeneration and restoration of the mutilated nose and ears of Surpanakha, Ravana's sister and princess of the Asuras, could also be found in the Ramayana.

The Hindu deity worshiping comprises the worship of Trimurti - Hindu Trinity of the creator of this universe named as Brahma, the preserver who takes care of the entire existence or Vishnu and the one who 
destroys the worlds or Shiva. Ayurveda is mainly associated with the deity Vishnu, or the preserver. Some of Vishnu's devotees, for example, Narada can continue to exist even though the cycles of destruction and creation of the universe, and this makes Narada literally immortal. Vishnu is prophesied to reincarnate as Kalki. Kalki seems to possess all the features of an artificial superintelligence (ASI).

Kalki is believed to be the tenth avatar of Hindu god Vishnu who would put an end to the Kali Yuga. In Vaishnavism cosmology, there are four periods in an endless cycle of existence (krita) and Kali is the final period. He is depicted in the Puranas as the avatar who recreates the universe by putting an end to the most chaotic and dark period of existence. He is prophesied to and removes "adharma" or evil to usher the Satya Yuga, the new beginning of another cycle. He happens to be an invisible force which is going to destroy all chaos and evil to establish harmony and peace, much like the hypothesized Artificial Super Intelligence of the future [25].

The concept of Vimāna or a mythological flying palace or chariot can be found in Ramayana. Other Hindu texts and Sanskrit epics also mention the concept. The most quoted example of a vimana is the Pushpaka Vimana of the king Ravana (who took it from Lord Kubera; Rama returned it to Kubera [24] Such a concept synonymous to the flying machines of the modern day like the fighter jet or airplanes.

Similar to modern Nuclear weapons, Brahmanda Astra was an ancient mystical weapon, which was used in numerous warfares in the Hindu mythologies. Such weapons were collectively named as Brahma weapons or brahmastra in different narrations of Mahabharata, Ramayana and the Puranas. The weapon called Brahmashirsha Astra could destroy the world. The Universe could be annihilated by the Brahmanda Astra [26]. Brahmastra never misses its target, could be obtained by meditating upon Brahma and is depicted as a fiery weapon which can create a fireball to annihilate the whole world [27]. The after effects of the destruction is indicated by a fatal decrease in rainfall and occurrence of drought. The epics and Vedas advice the use of the Brahmastra as a last recourse and warns against its use in a casual combat. The description of the Brahmastra as in the Mahabharata goes as - "A weapon, which is said to be a single projectile charged with all the power of the universe".

Rejuvenative and regenerative technologies along with technologies that are used in modern warfare and the predictive narrative of future artificial intelligence have been elaborately envisioned in ancient Hindu scriptures.

\section{Transhumanist connections in Indian religion: Buddhism}

Buddhism is originally an Indian religion, which is also now the world's fourth-largest religion. Buddhism is an embodiment of a number of eclectic traditions, beliefs and spiritual practices with Lord Buddha's teachings at the centre of the stage. Buddhism germinated in India between the 6th and 4th centuries BCE, and then it had proliferated across Asia. In the Buddhist texts, it is found that Amitābha is the Great Buddha who endows perpetuity. He is the "Buddha of Infinite Light", or in better words, Amitāyus, or the "Buddha of Infinite Life". It is said that "Those who invoke him will reach longevity in this realm, and will be reborn in Amitabha's Pureland (Sukhāvatī or Dewachen in Tibetan Buddhism) where they will enjoy virtually unlimited longevity." Amitabha's avowed devotion and perseverance helped him to create this sacred and equalitarian land."Om amrita teje hara hum" (Om save us in the glory of the Deathless One hum) is a mantra chanted in the appraisal of Amitabha. Many Buddhist mantras are allocated towards the healing of the old age and are chanted to extend longevity. They believed that these would help to open the portals of their wisdom and connect them to the ONE and thus suffering would be abolished by practicing compassion and extreme longevity can be reached in this world itself. Along with the spiritual aspect, medical means or physical means for rejuvenation and longevity have also been developed by the wise Buddhist physicians [28]. 
In Buddhist eschatology Maitreya (Sanskrit), Metteyya (Pali), is deemed as the future Buddha of this realm. He is referred to as Ajita in Buddhist literature such as in the Amitabha Sutra and the Lotus Sutra. The Buddhists believe that Maitreya is a bodhisattva (Buddha or pure consciousness) who will emerge on the terrestrial world in the future, who will attain total enlightenment, and teach the pure dharma (cosmic law and order) to people. The Buddhists texts predict that Maitreya will succeed the past Buddha; Gautama Buddha (also called as Śākyamuni Buddha). The prophecy of the arrival of Maitreya directs towards a point of time in the future when the dharma will have been obliviated by the humans and most of the planet earth is shrouded in chaos and darkness [29].

The arrival of Maitreya is alike to the arrival of an Artificial Super Intelligence (ASI) on this earth to usher an age of harmony, peace, and order when most of the world is immersed in chaos.

Thus akin to Hinduism, Buddhism too has a strong parallelism to the quest of attaining longevity and moksha (or enlightenment). In addition, there is a prediction of the arrival of a sentient being like the artificial intelligence so predicted by the modern technological trends [30] who would deliver the people of this world from chaos to harmony.

\section{Transhumanism in contemporary India}

In the present status, the World Transhumanist Association (WTA) has provided a formal definition of transhumanism: "The intellectual and cultural movement that affirms the possibility and desirability of fundamentally improving the human condition through applied reason, especially by developing and making widely available technologies to eliminate aging and to greatly enhance human intellectual, physical, and psychological capacities [31]." This philosophy of transhumanism is a based on the continually evolving framework of principles, values, and perspectives based on the idea that new scientific and technological developments are likely to remove the limits of our physical, biological and intellectual inheritance. Transhumanists believe and support the idea that potential future technologies like gene editing, nanotechnology, artificial intelligence, regenerative medicine, biotechnology, cryonics, radical life extension, mind uploading etc. have a potential to enhance human conditions in every possible way, even ending aging [1].

Over the years, India has made significant progress in its goal to bring millions of people out of extreme poverty that correlated with high immortality. A lot of the progress was a direct consequence of the advancements in science and technology. There are a number of technologies that can have a disruptive impact on government, society, and importantly on individual life. From the basic technological advancement for e.g. Mobile internet, digital payments, work automation, digital verification identity systems. Future of 5G-telecommunication technology will also play a huge role in automating and leveraging on data from real-time distributed systems. Beyond digitization, the rapid advances in genomics, intelligent transportation, energy (renewables, storage, gas, and oil), medicine, advanced geographic information systems, artificial intelligence can help India build a more efficient power supply and distribution systems, raise individual productivity, improve basic income and healthcare access, curb corruption and more.

India has good reasons to be optimistic given the recent record of accomplishment of technological and its economic growth over the years, especially among young population demographically. India, being the world's largest democracy, with the population of 1.35B (2018) [32], makes up for a total of $17.74 \%$ of the world population. In contrast to USA, Europe and East Asia with their aging societies, India is a relatively young country with $50 \%$ of the population not older than 25 . In addition to the IT sector, India is moving towards the forefront of genuine innovation in pharmaceuticals, manufacturing and biotechnology sectors. Recent increase in budget allocation by the Indian government in science, research and development particularly focussed more in the field of robotics, artificial intelligence, big data analysis, quantum 
communication, Internet of Things Space and Atomic energy is a proof that India is adopting towards a rational, action-based optimism and shunning blind faith at the same time.

Despite the fact that India's population demographic is relatively young with a median age of $\mathrm{x}$ years, life expectancy is still comparatively low at an average of 66.8 years [32-34]. Thus, it is likely that the dynamic and optimistic young generation will especially embrace technologies for longevity and human enhancement to tackle most physical and mental health-related problems, workplace safety, unemployment, pollution and more.

India faces many problems ranging from medicine (health care access, drugs, genetic diseases, high child mortality rate, etc.) to agriculture (low-yield crops, farmer suicide rate, pesticide use) to education (unequal access, illiteracy rate) to gender inequality and more. Nevertheless, these problems can be potentially alleviated by adopting emerging technologies. Transhumanism in India can potentially be more successful than in western countries particularly because Indic religions are perceived to be more open to the ideologies supporting human improvement.

Zoltan Istvan (founder of the US Transhumanist Party and candidate for the 2016 US Presidential election on behalf of this party) even said, "Many transhuman goals, like trying to overcome human death, go against the grain of Western religions and their sacred texts. But Hinduism, Buddhism, and various other Eastern religions can be conducive for transhumanism and its goals." Other reasons why such an ideology can be more fertile in India are: entrepreneurial spirit among millennials, current government support with organizations like Make in India [35], Invest India [36] etc., opportunity to catering to the needs of a large population and freedom to use science and technology as a canvas to express creativity. "In the United States, for example, it takes sometimes a decade to get a drug or certain type of technology approved by the government, into production, and then into the public's hands. In India, there is far less scientific bureaucracy and government approval. It is felt that, due to these reasons, transhumanist technologies will probably grow a lot faster in places like India rather than in the West", adds Istvan.

\section{Emerging technologies tending toward Transhumanism in India}

Healthcare is one of the major emerging sectors in India which shown major development and breakthrough over the past few years in India. In India, healthcare sector divided into public and private form, where the private healthcare sector is a dominant service provider while public healthcare is free for those below the poverty line. The private sector exists and favourable among the public due to a better quality of service, access to high-tech facilities, world-renowned experienced doctors. Indian government took and taking several initiatives like The Twelfth Plan, Public-private partnership, National Rural, and Urban Health Mission schemes to strengthen the overall structure including infrastructure, research, and development.

Although, there is a big gap when it comes to healthcare outreach among the second largest population of India probably due to inequalities in healthcare access like insufficient access to healthcare facilities and differential distributions of services, power, and resources. The main bottleneck in Indian healthcare ecosystem is the "access" to the services that are also a big reason behind major development in the field, significant government as well private interest. One of the important and feasible ways is to tackle in nearby future is by leveraging the use of new and emerging mobile and connected technologies to enable proactive healthcare system. From simple wrist-based accelerometers to smartphones that capture heart rate, blood pressure, and glucose measures, technology has evolved beyond common health and fitness tracking. Such technologies include disposable vital-sign patches (to transmit streaming ECG, posture, temperature, stress data), smart bed sensors (to track the quantity and quality of sleep), consumer EEGs (to measure brainwaves), trainables (such as Upright, a device that buzzes your back when slouching to entrain a better posture), scales (to track vitals and measure BMI, fat/muscle percentage etc.), BP cuffs, sensor-fitted pacifiers (to analyse alcohol consumption, to track hydration status and molecules that can indicate a 
metabolic or malignant disease) and more. With these technologies comes the possibility and promise to connect all the data dots at meaningful scales. The emergence of real-world AI will significantly improve the efficiency of diagnosis and hence the front line delivery and the future of healthcare in India. Which also inspire the government toward focusing intensely on full fledge development plan for artificial intelligence under the banner hash-tag AI for all, as found in the June 2018 Discussion Paper on National Strategy for Artificial Intelligence [37].

The Government of India also made several changes in existing policies for better future of healthcare in India by commitment toward the Universal Health Coverage and increased access to comprehensive primary health care by launching the schemes like Ayushman Bharat programme in 2018 [38], known to be the world's largest government-funded health care programme, which directly impact the wellbeing of individuals thus the longer life expectancy.

The Government of India is investing heavily toward the future for Health and Wellness Centres (HWC), which will lay the foundation for the future of India's health system as envisioned in the National Health [38]. These HWCs, to be set up by transforming 1.5 lakh Health Sub Centres from 2018 to 2022, are aimed at shifting primary healthcare from selective (reproductive and child health / few infectious diseases) to comprehensive (including screening and management of NCDs; screening and basic management of mental health ailments; care for common ophthalmic and ENT problems; geriatric and palliative health care, and trauma care and emergency care).

In parallel to a bunch of introduction of government policies, the personalized medicine technologies is another growing field in India. Personalized medicine uses a patient's unique clinical, genetic, genomic, and environmental information to make intelligent diagnosis and predictions regarding susceptibility towards a particular disease for that particular individual, probable responses and the course of the disease. The aim of personalized medicine is to make the treatment as individualized as the disease itself by identifying genetic, genomic and clinical problems. Molecular diagnostics are used to detect changes in the DNA, RNA and protein expression level of the patient, which subsequently helps to detect any changes in the genes and thus helps in the early detection and diagnosis of the disease. Patients can have an insight about their problems and can monitor disease progression and select appropriate therapies, which can be exclusively personalized to their biology. A great example can be of cancer; which kind of cancer patient will respond to the particular kinds of therapeutic interventions can be determined by molecular diagnostic tests instead of just administering the traditional chemotherapy that was the exclusive and universal treatment for cancer in the past decade.

Growth in Personal Genomics Technology field is helping in preventive health care, disease burden reduction and Personalized Medicine in India. Positive Bioscience has teamed up with Medanta - The Medicity to launch a genomics clinic, which is first of its kind in India. This initiative will serve personal genomics in tandem with the expert medical diagnosis. Advancements in the field of personal genomics now allow the scientists to run a genetic test for any individual and then make a prediction whether or not the individual has the propensity to develop a particular kind of disease or not along with the compatibility of the individual's metabolism to a particular group of drug. All of these have led to much development in the field of pharmacogenomics, which is hence helping the big pharma companies to eliminate the unpredictability associated with the process of developing a drug. Start-up companies like Xcode Life Sciences are following this model by providing solutions for lifestyle-related diseases like diabetes, coronary heart diseases, and obesity. They ship a saliva kit to the customers who have ordered online for a test and then later use the non-invasively collected saliva to extract DNA and determine the allelic information using the high throughput genotyping techniques. A company called NutraGene launched the first commercial genetic test for type 2 diabetes in India. 
Although the application of genomic and personalized medicine in India seems to be a very promising field in ushering the new era in medical sciences, there are many hurdles on the way. The effectiveness of the methodologies has to be critically assessed by the researchers, diagnostic firms and regulatory authorities and the application of such technology in India smoothly needs a change in the regulatory system.

On the other hand, much exaggerate technology, CRISPR also playing an important role in health-related technology in India. CRISPR is a gene-editing tool that is able to snip the mutation caused in the sickle cell anemia [39]. Beta thalassemia is the most prevalent blood-related genetic disorder in India and thus scientists at Institute of Genomics and Integrative Biology (IGIB), Delhi is trying to use the technology to form the basis of a viable therapy. However, there are certainly ethical issues regarding CRISPR, which is being heavily debated throughout the globe. Since CRISPR, technology has the capability to alter the genetic makeup of an organism, the possibility of creating superhumans to designer babies raise a lot of ethical questions to which the Indian scientists respond with caution. Indian Government has banned the use of stem cell therapy for commercial use due to "rampant malpractices" however; the national guidelines do permit the use of stem cells in certain blood cancer types [40].

The upgraded medical system, personalized medicine, CRISPR has a huge potential to increase the wellbeing of the current population in India. However, taking into the account that there will be a rise in the aged population as well, the need for a more holistic care is also required investigation. The geriatric population in developing country like India is expected to be 840 million by 2025 . The proportion of Indians that would be aged 60 years or above will rise from $7.5 \%$ in 2010 to $11.1 \%$ in 2025 . The number of elderly population was 91.6 million in 2010 and that is projected to increase to 158.7 million in 2025 [41].

The Longitudinal Aging Study in India (LASI) was funded by an R21 exploratory grant from the National Institute on Aging (NIA), one of the 27 institutes and centres of the National Institutes of Health (NIH). LASI aims at understanding the situation of the elderly population in India with precise details so that the design of policymaking to support and protect the elderly can be done effectively.

LASI uses two main tools; first, the computer-assisted personal interview (CAPI) techniques to register the answers given by the survey contributors. (The funding for this study comes from the pilot grant from Harvard's Program on the Global Demography of Aging [PGDA]); and second, molecular biomarker collection, which can be studied to obtain quantitative data on the status of health of the participants. The National Research Council advised that biomarker collection should be included in a social survey to (a) obtain data regarding health from a part of the population that otherwise would not have got such type of information on the records ; (b) probe the determining factors on a molecular level for common health outcomes and (c) investigate interactions that might later lead to decline in the health outcomes. Interactions such that between biomarkers and other social conditions. It is important to include factors like biomarkers and other medical assessments in less-developed countries like India, where procuring even basic health care is quite difficult. Hence, unlike developed countries, undiagnosed diseases tend to be common in India. [42].

There is also some organization related to aging in Indian like Avesthagen, which is a major player focusing on the pharmacogenomics of aging in the Parsi population in India. One of the major projects started under 125 crore at 2007 is the AVESTA GENOME project. The company does a system biology-based study regarding the genetic basis of longevity and geriatric disorders in the Parsi community. The aim of the study is to design a model for pharmacogenomics-based therapies on ageing, develop biomarkers for predictive diagnostics and drug discovery. Also by this study, the genome of the Parsi community is going to be archived [43].

The key highlight here is that India got the diverse ethnic demographics and has the potential to be a key player in longevity research. According to Prof. Kalluri Subba Rao, Hon. Coordinator for Center for 
Research and Education in Aging (CREA), University of Hyderabad, India, "Science Academies have a responsibility to alert the Government authorities for initiating ventures that would stabilize a social climate in terms of health and economics. Aging research in the lines cited above, in my opinion, would be one to contribute such a climate [44].“

Apart from the Indian Government, policies toward the healthcare, advancement in technology related to health care and aging research, India open his door for other countries to enjoy the fruits of these researches. Such policy gave a significant rise in Medical tourism.

India is considered as one of the fastest emerging medical tourism destinations in the world and growing as sector worth more than $\$ 3$ billion back in till 2015 and is projected to be worth $\$ 8$ billion by 2020 . Main reasons why India attracts foreigners to get medical treatments here are a competitive cost advantage, availability of the latest medical technologies and other accredited facilities that are at par with those in developed countries. Patients without Borders, a US-based medical travel resource, says certain medical procedures in India cost around one-tenth of the price in the United States, making it one of the cheapest places to get the treatment. Most common treatments sought in India by tourists are heart surgery, hip replacement or resurfacing, bone-marrow transplants, eye surgery, cardiac bypass surgery, dental care etc. Although most of the medical tourists come to India from the Middle East and neighbouring Asian countries like Bangladesh, Afghanistan, Maldives, Republic of Korea and Nigeria, it is fast emerging as a hotspot for medical tourism from US and Europe as well [45].

The transhumanism discourse offers an ongoing debate on the different standpoints that has flourished as an outcome of a contemporary attempt to redefine human condition. On speculating and reflecting past, present and future of transhumanism in India - current understanding and awareness of the transhumanist reflection is not necessarily known by the exact definition/movement but the ultimate goal identifying the use of speculative scientific framework and emerging technologies to enhance human condition is deeply inscribed and reflected by different policy around the world. India has the economic potential, and the perfect playground for disruption from emerging technologies at multiple levels of healthcare, smart cities, agriculture, automated agents ( intelligent machine), and space exploration with AI-driven solutions, as evident by the increasing activity from large corporates, startups including government agencies like ISRO. One can argue that these ideologies from ancient India, government intervention toward disruptive technologies, public and private support, youngest population in the world, and freedom to use science and technology as a canvas to express creativity are the clear sign that India will able to lead and drive the world toward the future of transhumanism

\section{References:}

1. Bostrom, N., A history of transhumanist thought. Journal of evolution and technology, 2005. 14(1): p. 1-25.

2. Bose, S. and A. Jalal, Modern South Asia: history, culture, political economy. 2002: Routledge.

3. Constitution of India. 1949.

4. $\quad$ Pargiter, F.E., Ancient Indian historical tradition. 1997: Motilal Banarsidass Publishe.

5. Thapar, R., The Penguin history of early India: from the origins to AD 1300. 2015: Penguin UK.

6. Schmidt, H.P., Notes on Rgved. Indica. Organ of the Heras Institute,, 1980. 17.

7. Singh, U., A history of ancient and medieval India: From the Stone Age to the 12th Century. 2009: Delhi: Longman.

8. Reading the Vedic Literature in Sanskrit. [cited 201711 December 2017]; Available from: is 1.mum.edu.

9. Kenoyer, J.M. and K.B. Heuston, The Ancient South Asian World. 2005: Oxford University Press, USA.

10. Baker, K.M. and G.P. Chapman, The Changing Geography of Asia. 2002: Routledge. 
11. Keay, J., India: A History. Revised and Updated. 2011: Grove/Atlantic, Inc.

12. Stafford, N., Finding Lost: The Unofficial Guide. 2006: Ecw Press.

13. Prakash, O., Cultural History of India. 2005: New Age International.

14. Reich, D., et al., Reconstructing Indian population history. Nature, 2009. 461(7263): p. 489.

15. Ranadive, B.T., India's Freedom Struggle. Social Scientist, 1986: p. 81-126.

16. Flood, G.D., An introduction to Hinduism. 1996: Cambridge University Press.

17. Prama, R., India: Science and Technology from Ancient Time to Today. Technology in Society, 1997. 19(3-4): p. 415-447.

18. Witzel, M., ed. The Development of the Vedic Canon and its Schools : The Social and Political Milieu. Inside the Texts, Beyond the Texts. 1997, Harvard Oriental Series.

19. Griffith, R.T.H., The Rig Veda. 1896.

20. Bhishagratna, K.K.L., Suśruta and Kunjalal Bhishagratna: An English Translation of the Sushruta Samhita, in Translation of Different Readings. 1907.

21. Madan, G., India through the ages, M.o.I.a. Broadcasting, Editor. 1990. p. 66.

22. Van Loon, G., Charaka Samhita: Handbook on Ayurveda. Volume I-PV Sharma \& Chaukhambha Orietalia, 2003.

23. Parva, S., Sabha Parva. Mahabharata, 1993. 2: p. 108.

24. Griffith, R.T.H., The Rámáyan of Válmíki: Translated Into English Verse. Vol. 1. 1870: Trübner and Company.

25. Dalal, R., Hinduism: An Alphabetical Guide. 2010: Penguin Books India.

26. Dutt, M.N., Ramayana. 1892, Calcutta: Elysium Press.

27. The Matsya Puranam. 1916: Pâninini Office.

28. Maher, D.F., Two Wings of a Bird: Radical Life Extension from a Buddhist Perspective, in Religion and the Implications of Radical Life Extension. 2009, Springer. p. 111-121.

29. S, P.C., The Minor Anthologies of the Pali Canon. Part IV: Vimannavatthu: Stories of the Mansions. Journal of the American Oriental Society, 1980. 100: p. 56.

30. Müller, V.C. and N. Bostrom, Future progress in artificial intelligence: A survey of expert opinion, in Fundamental issues of artificial intelligence. 2016, Springer. p. 555-572.

31. The Transhumanist FAQ: v 2.1. World Transhumanist Association 2003. . [cited 2018 7-Oct-18]; Available from: http://transhumanism.org/index.php/WTA/faq/.

32. Countrymeters. [cited 2018 07-October-2018]; Available from: https://countrymeters.info/en/India.

33. Davendra Verma, et al., Youth in India, S.S.D.C.S.O.M.o.S.P. Implementation, Editor.

34. Worldometers. [cited 2018 08-October-2018]; Available from: http://www.worldometers.info/world-population/india-population/.

35. $\quad$ Focus on Make In India. 2014.

36. Invest India. 2018 [cited 2018 07-October-2018]; Available from: https://www.investindia.gov.in/.

37. Roy, A., National Strategy for Artificial Intelligence, N. Aayog, Editor. 2018, NITI Aayog.

38. Ayushman Bharat - National Health Protection Mission. 2018 [cited 2018 07-October-2018]; Available from: https://www.india.gov.in/spotlight/ayushman-bharat-national-health-protectionmission.

39. $\mathrm{Xu}, \mathrm{P}$., et al., Both TALENs and CRISPR/Cas9 directly target the HBB IVS2-654 (C> T) mutation in $\beta$-thalassemia-derived iPSCs. Scientific reports, 2015. 5: p. 12065.

40. Jotwani, G. and S.D. Sinha, National Guidelines For Stem Cell Research I.C.o.M.R.D.o. Biotechnology, Editor. 2017, Indian Council of Medical Research: New Delhi.

41. Mane, A.B., Ageing in India: Some Social Challenges to Elderly Care. J Gerontol Geriatr Res, 2016. 5: p. e136.

42. Longitudinal Aging Study in India (LASI). [cited 2018 07-October-2018]; Available from: https://www.hsph.harvard.edu/pgda/major-projects/lasi-2/. 
43. Guzder, S., et al., The AVESTAGENOME project ${ }^{\mathrm{TM}}-$ a discovery model for disease genomics and beyond. Genome Biology, 2010. 11(1): p. P16.

44. Centre for Research and Education in Ageing. Available from:

http://www.uohyd.ac.in/index.php/academics/2011-10-27-18-38-44/research-and-education-inageing.

45. PTI, Indian medical tourism industry to touch $\$ 8$ billion by 2020: Grant Thornton in The Economic Times. The Economic Times: Online. 